\title{
Peran Pelayanan Sekolah Dasar Dalam Mendukung Kota layak ANAK Di SURAKarTa
}

\author{
M Dhia Subulussalam, Murtanti Jani Rahayu, Rizon Pamardhi Utomo \\ Program Studi Perencanaan Wilayah dan Kota, \\ Jurusan Arsitektur, Fakultas Teknik \\ Universitas Sebelas Maret, Surakarta \\ email: subulussalam@ rocketmail.com
}

\begin{abstract}
Surakarta city is one of the first five cities that became a model in applying the concept of child friendly city. As one of the city that became the modeling of the concept of child friendly city, the city of Surakarta has made many changes to be able to realize the concept. But in Surakarta decent towards the child does not mean there are no issues. One of the problem that happens is in the field of education, especially primary schools like a gap of educational standards, filling the needs of the educational infrastructure is still not fulfilled, and the safety and comfort of children both within and outside the school. Issues contained in the education sector will have a negative impact in the process of realizing the child friendly city in Surakarta. Research question is how the role of primary education in creating child-friendly city in Surakarta. The research method is the type of deductive quantitative research with technique analysis is descriptive quantitative and descriptive spatial by describing the spatial conditions in the field. The results of this researchis that the majority of elementary schools in Surakarta has a range of services that exceed the ideal standard, completeness infrastructure elementary school environment that is still not fullest yet and therefore have the safety and comfort on the road around the school is quite high. From the results obtained that the role of primary school services in support of child friendly city is still providing a sense of safety and comfort, although the condition of completeness lack of infrastructure facilities and elementary school services is far enough.
\end{abstract}

Keywords: child friendly cities, elementary school, the role of education service

\section{PENDAHULUAN}

Kota Surakarta merupakan salah satu dari lima kota pertama yang menjadi model dalam menerapkan konsep kota layak anak dalam Peraturan Menteri Negara Pemberdayaan Perempuan dan Perlindungan Anak Nomor 2 Tahun 2009 tentang Kebijakan Kota Layak Anak (KLA). Sebagai salah satu kota yang menjadi permodelan dari konsep Kota Layak Anak (KLA) Kota Surakarta sudah banyak melakukan perubahan untuk dapat mewujudkan konsep tersebut. Namun dalam menuju Surakarta layak anak bukan berarti tidak ada kendala yang dihadapi. Dalam hal fasilitas pendidikan dasar yang menjadi fokus dari penelitian ini, Kota Surakarta dengan jumlah penduduk sekitar 500 ribu jiwa memiliki jumlah fasilitas pendidikan tingkat sekolah dasar (SD) berjumlah 268 sekolah (SDA, 2013) sedangkan menurut acuan dari SNI 031733-2004 tentang Tata Cara Perencanaan Lingkungan Perumahan di Perkotaan, satu sekolah dasar melayani sekitar 1600 jiwa, jadi dengan jumlah penduduk yang ada di Kota Surakarta seharusnya memiliki sekolah dasar sebanyak 312 sekolah untuk dapat melayani kebutuhan fasilitas pendidikan tingkat sekolah dasar.

Dengan jumlah sekolah dasar yang di bawah kebutuhan dan dengan ditetapkannya Kota Surakarta menjadi percontohan model kota layak anak tentu memiliki permasalahan di bidang pendidikan. Permasalahan tersebut berupa kurangnya jumlah sekolah dasar dan persebaran yang tidak merata ditambah dengan masih adanya anak putus sekolah dan anak tidak mampu untuk mengenyam pendidikan yang layak. Hal ini memunculkan pertanyaan besar mengenai 
pelayanan pendidikan yang diberikan dalam upaya mewujudkan kota layak anak di Kota Surakarta.

Di sisi lain, terdapat permasalahan mengenai kesenjangan standar pendidikan di Kota Surakarta, sehingga terdapat sekolah yang tertinggal dan sekolah yang "tersoroti" atau disebut sebagai fenomena sekolah favorit. Fenomena ini disebabkan oleh kualitas dari masing-masing sekolah dasar yang terus meningkat. Kebanyakan fenomena sekolah favorit terbentuk dengan sendirinya berdasarkan lulusan yang dihasilkan sehingga mencerminkan bahwa sekolah tersebut berhasil mendidik siswa/siswi dengan benar. Selain itu, pemberitaan media massa mengenai prestasi-prestasi yang telah diraih sekolah tersebut memunculkan stigma masyarakat tentang kualitasnya. Dengan beredarnya pembicaraan mengenai sekolah mana yang dianggap berkualitas dan sekolah mana yang dianggap kurang berkualitas memberikan dampak terhadap perbedaan pelayanan yang diberikan masing-masing sekolah untuk tetap dapat mempertahankan status tersebut. Sekolah yang sudah dianggap favorit memberikan pelayanan lebih seperti metode pembelajaran yang berbeda, fasilitas yang diberikan, sarana prasarana yang memadai atau dengan adanya program-program khusus yang tidak ada dalam sekolah yang dianggap non favorit. Beberapa hal tersebut yang menjadi penyebab calon murid/orang tua murid lebih memilih sekolah dengan kualitas terbaik, walaupun jarak yang harus ditempuh lebih jauh dari sekolah dengan kualitas standar atau kurang namun berada dekat dengan rumahnya. Hal tersebut berdampak pada perjalanan pergi dan pulang sekolah yang harus diantar dan dijemput karena jarak yang ditempuh tidak memungkinkan untuk berjalan kaki.

$$
\text { Melihat fenomena dan }
$$

permasalahan mengenai pendidikan yang ada, terjadi pertentangan dengan konsep kota layak anak yang sedang diterapkan di Kota Surakarta dan skala dari sekolah dasar yang seharusnya aman bagi anak-anak melakukan kegiatannya. Mengacu pada permasalahan tersebut timbul pertanyaan peneliti, Bagaimanakah peran pelayanan pendidikan dasar dalam mendukung kota layak anak di Surakarta?

\section{METODE PENELITIAN}

Penelitian ini merupakan penelitian kuantitatif dengan menggunakan pendekatan deduktif di mana dalam merumuskan variabel menggunakan teori sehingga diketahui kebutuhan data yang akan digunakan.

Konsep peran dalam penelitian ini adalah terkait kontribusi yang dilakukan terhadap suatu pekerjaan atau tugas/fungsi yang dimiliki terhadapnya. Untuk melihat peran antara satu hal terhadap hal lainnya dapat diartikan dengan melihat seperti apa kontribusi atau andil yang diberikan oleh satu hal tersebut terhadap hal lainnya.

Teknik pengumpulan data terbagi menjadi data primer dan data sekunder. Data primer didapatkan melalui observasi lapangan, wawancara dan kuesioner serta data sekunder didapatkan melalui studi dokumen/literatur.

Dalam mengumpulkan data yang dibutuhkan digunakan teknik sampel disproportionate stratified random sampling dikarenakan jumlah populasi yang tidak proporsional antara sekolah favorit dan sekolah non favorit sehingga dihasilkan sampel sekolah dasar sebanyak 60 sekolah yang dibagi menjadi dua klasifikasi yaitu sekolah favorit berjumlah 19 sampel dan sekolah non favorit berjumlah 41 sampel.

Dari 60 sampel sekolah dasar tersebut didapatkan sampel siswa sekolah dasar sebanyak 342 siswa yang dibagi kembali sesuai proporsi jumlah siswa tiap sekolah.

Teknik analisis yang digunakan dalam penelitian ini secara garis besar menggunakan analisis secara deskriptif kuantitatif dan spasial. Penelitian ini merupakan penelitian studi kasus dengan metoda observasi langsung ke lapangan kemudian diproses menggunakan analisis deskriptif kuantitatif dan spasial. Analisis yang digunakan terdiri dari tiga tahapan yaitu:

1. Mengetahui jangkauan pelayanan terjauh dari sampel sekolah dasar dengan teknik analisis deskriptif kuantitatif dan spasial.

2. Mengetahui kelengkapan sarana prasarana lingkungan sekolah dasar 
dengan teknik analisis deskriptif kuantitatif.

3. Mengetahui keamanan dan kenyamanan di jalan sekitar sekolah dasar dengan teknik analisis deskriptif kualitatif

4. Mengetahui peran pelayanan sekolah dasar dalam mendukung kota layak anak dengan teknik analisis deskriptif berdasarkan hasil skoring.

\section{HASIL DAN PEMBAHASAN}

\subsection{Analisis jangkauan pelayanan}

Jangkauan yang digunakan adalah jarak terjauh dari sampel siswa tiap sekolah karena jarak terjauh menunjukkan jangkauan pelayanan sekolah dasar yang sebenarnya.

Hasil survey lapangan mengatakan tidak terdapat sekolah dasar pada klasifikasi sekolah favorit yang memiliki jangkauan pelayanan sekolah antara 400-800 meter, sedangkan pada klasifikasi sekolah non favorit terdapat tujuh sekolah dasar atau sebesar 17,1\% sekolah dasar non favorit yang memiliki jangkauan pelayanan sekolah antara 400800 meter. Secara keseluruhan dari 60 sampel sekolah dasar di Kota Surakarta terdapat tujuh sekolah dasar atau sebesar $11,7 \%$ sekolah dasar yang memiliki jangkauan sekolah dasar 400-800 meter dan terdapat sebesar $88,3 \%$ atau 53 sekolah dasar dari total sampel yang memiliki jangkauan di atas dari 800 meter, yaitu keseluruhan sekolah dasar yang berada pada klasifikasi sekolah favorit dan $82,9 \%$ atau sebanyak 34 sekolah dari klasifikasi non favorit. Untuk melihat jangkaun pelayanan sekolah dasar favorit dan non favorit dapat melihat peta lampiran.

\subsection{Analisis kelengkapan sarana prasarana lingkungan sekolah dasar}

Kelengkapan sarana prasarana lingkungan sekolah dasar merupakan salah satu penilaian untuk mengukur peran pelayanan pendidikan dasar dalam mendukung kota layak anak, fasilitas yang diambil adalah yang memiliki keterkaitannya dengan konsep kota layak anak, yaitu taman bermain/lapangan yang berada dalam sekolah dan fasilitas external di sekitar sekolah juga turut diteliti yang menyangkut pelayanan terhadap sekolah dasar, di antaranya adalah: jalur pedestrian, Zoss/zebra cross, pembatas jalan, marka kejut/polisi tidur, peneduh jalan, tempat beristirahat, dan petanda jalan.

\subsubsection{Taman Bermain/Lapangan}

Keberadaan fasilitas ini dianggap penting karena pada usia anak-anak bermain merupakan metode belajar yang paling mudah diserap anak dan akan meningkatkan kreativitas anak.

Hasil survey lapangan mengatakan keseluruhan sampel sekolah dasar pada klasifikasi sekolah favorit memiliki taman bermain/lapangan dan berfungsi dengan baik, sedangkan pada klasifikasi sekolah non favorit terdapat 35 sekolah dasar atau sebesar $85,4 \%$ sekolah dasar non favorit yang memiliki taman bermain/lapangan dan berfungsi dengan baik. Secara keseluruhan dari 60 sampel sekolah dasar di Kota Surakarta terdapat 54 sekolah dasar atau sebesar $90 \%$ sekolah dasar yang memilikitaman bermain/lapangan yang berfungsi dengan baik dan terdapat sebesar $10 \%$ atau enam sekolah dasar dari total sampel yang tidak memiliki taman bermain/lapangan, yaitu berasal dari sekolah dasar yang berada pada klasifikasi sekolah non favorit sebanyak $14,6 \%$ atau 6 sekolah dasar sehingga anak-anak yang berada pada sekolah yang tidak memiliki taman bermain/lapangan melakukan kegiatan bermain/olahraga di luar sekolah.

\subsubsection{Jalur Pedestrian}

Jalur pedestrian merupakan fasilitas utama bagi para pejalan kaki. Keberadaan jalur pedestrian menjadi penting karena sekolah dasar memiliki jangkauan ideal untuk berjalan kaki dan pelaku perjalanan tersebut adalah anakanak.

Hasil survey lapangan mengatakan terdapat delapan sampel sekolah dasar atau sebesar 42,1\% pada klasifikasi sekolah favorit yang memiliki jalur pedestrian dan berfungsi dengan baik di sekitar sekolahnya dan sebesar 57,9\% atau 11 sekolah dasar favorit tidak memiliki jalur pedestrian di sekitar sekolahnya, sedangkan pada klasifikasi sekolah non favorit terdapat lima sekolah dasar atau sebesar 12,2\% sekolah dasar 
non favorit yang memiliki jalur pedestrian dan berfungsi dengan baik di sekitar sekolahnya namun terdapat dua sekolah atau sebesar 4,9\% sekolah non favorit yang memiliki jalur pedestrian tapi tidak berfungsi dengan baik, dapat di lihat pada Gambar 4.5 dan 82,9\% atau 34 sekolah non favorit yang tidak memiliki jalur pedestrian. Secara keseluruhan dari 60 sampel sekolah dasar di Kota Surakarta terdapat 13 sekolah dasar atau sebesar $21,7 \%$ sekolah dasar yang memiliki jalur pedestrian yang berfungsi dengan baik dan terdapat sebesar $75 \%$ atau 45 sekolah dasar dari total sampel yang tidak memiliki jalur pedestrian.

\subsubsection{Zona Selamat Sekolah (ZOSS)/Zebra Cross}

Zona selamat sekolah berada tepat di area depan sekolah dengan ditandai dengan cat berwarna merah untuk member peringatan kepada pengguna jalan bahwa mereka memasuki areal sekolahan dan juga terdapat zebra cross sebagai jalur penyebrangan untuk anak-anak.

Hasil survey lapangan mengatakan terdapat 12 sampel sekolah dasar atau sebesar $63,2 \%$ pada klasifikasi sekolah favorit yang memiliki zoss/zebra cross dan berfungsi dengan baik di sekitar sekolahnya dan sebesar $36,8 \%$ atau tujuh sekolah dasar favorit tidak memiliki zoss/zebra cross di sekitar sekolahnya, sedangkan pada klasifikasi sekolah non favorit terdapat tujuh sekolah dasar atau sebesar $17,1 \%$ sekolah dasar non favorit yang memiliki zoss/zebra cross dan berfungsi dengan baik di sekitar sekolahnya dan $82,9 \%$ atau 34 sekolah non favorit yang tidak memiliki zoss/zebra cross di sekitar sekolahnya. Secara keseluruhan dari 60 sampel sekolah dasar di Kota Surakarta terdapat 19 sekolah dasar atau sebesar $31,7 \%$ sekolah dasar yang memiliki zoss/zebra cross yang berfungsi dengan baik dan terdapat sebesar $68,3 \%$ atau 41 sekolah dasar dari total sampel yang tidak memiliki zoss/zebra cross.

\subsubsection{Pembatas Jalan}

Pembatas jalan berfungsi untuk membedakan lajur utama dan bahu jalan atau dengan jalur pedestrian sehingga dapat mengurangi kemungkinan terjadinya kecelakaan antara pengguna kendaraan dengan pejalan kaki atau bangunan di pinggir jalan.

Hasil survey lapangan mengatakan terdapat 13 sampel sekolah dasar atau sebesar $68,4 \%$ pada klasifikasi sekolah favorit yang memiliki pembatas jalan dan berfungsi dengan baik di sekitar sekolahnya dan sebesar 31,6\% atau enam sekolah dasar favorit tidak memiliki pembatas jalan di sekitar sekolahnya, sedangkan pada klasifikasi sekolah non favorit terdapat 15 sekolah dasar atau sebesar 36,6\% sekolah dasar non favorit yang memiliki pembatas jalan dan berfungsi dengan baik di sekitar sekolahnya dan $63,4 \%$ atau 26 sekolah non favorit yang tidak memiliki pembatas jalan di sekitar sekolahnya. Secara keseluruhan dari 60 sampel sekolah dasar di Kota Surakarta terdapat 28 sekolah dasar atau sebesar $46,7 \%$ sekolah dasar yang memiliki pembatas jalan yang berfungsi dengan baik dan terdapat sebesar 53,3\% atau 32 sekolah dasar dari total sampel yang tidak memiliki pembatas jalan.

\subsubsection{Marka Kejut/Polisi Tidur}

Polisi tidur atau Marka Kejut biasa disebut juga sebagai Alat Pembatas Kecepatan sehingga bila kendaraan bermotor yang melaluinya akan diingatkan oleh getaran dan suara yang ditimbulkan bila dilalui oleh ban kendaraan.

Hasil survey lapangan mengatakan terdapat satu sampel sekolah dasar atau sebesar 5,3\% pada klasifikasi sekolah favorit yang memiliki marka kejut/polisi tidur dan berfungsi dengan baik di sekitar sekolahnya dan sebesar 94,7\% atau 18 sekolah dasar favorit tidak memiliki marka kejut/polisi tidur di sekitar sekolahnya, sedangkan pada klasifikasi sekolah non favorit terdapat lima sekolah dasar atau sebesar 12,2\% sekolah dasar non favorit yang memiliki marka kejut/polisi tidur dan berfungsi dengan baik di sekitar sekolahnya dan $87,8 \%$ atau 36 sekolah non favorit yang tidak memiliki marka kejut/polisi tidur di sekitar sekolahnya. Secara keseluruhan 
dari 60 sampel sekolah dasar di Kota Surakarta terdapat enam sekolah dasar atau sebesar $10 \%$ sekolah dasar yang memiliki marka kejut/polisi tidur yang berfungsi dengan baik dan terdapat sebesar $90 \%$ atau 54 sekolah dasar dari total sampel yang tidak memiliki marka kejut/polisi tidur.

\subsubsection{Peneduh Jalan}

Peneduh jalan dimaksudkan untuk para pejalan kaki yang akan melintasi jalur pedestrian agar merasa nyaman dalam berjalan kaki.

Hasil survey lapangan mengatakan terdapat sembilan sampel sekolah dasar atau sebesar 47,4\% pada klasifikasi sekolah favorit yang memiliki peneduh jalan dan berfungsi dengan baik di sekitar sekolahnya dan sebesar 52,6\% atau 10 sekolah dasar favorit tidak memiliki peneduh jalan di sekitar sekolahnya, sedangkan pada klasifikasi sekolah non favorit terdapat sembilan sekolah dasar atau sebesar 21,9\% sekolah dasar non favorit yang memiliki peneduh jalan dan berfungsi dengan baik di sekitar sekolahnya dan $78,1 \%$ atau 32 sekolah non favorit yang tidak memiliki peneduh jalan di sekitar sekolahnya. Secara keseluruhan dari 60 sampel sekolah dasar di Kota Surakarta terdapat 18 sekolah dasar atau sebesar 30\% sekolah dasar yang memiliki peneduh jalan yang berfungsi dengan baik dan terdapat sebesar $70 \%$ atau 42 sekolah dasar dari total sampel yang tidak memiliki peneduh jalan.

\subsubsection{Tempat Beristirahat}

Pada umumnya setiap jalur pedestrian diharapkan dapat menyediakan tempat beristirahat terutama bagi jalur pedestrian yang memiliki jarak cukup panjang. Tempat beristirahat tersebut dapat berupa bangku-bangku yang dapat digunakan para pejalan kaki untuk bersantai atau hanya sekedar menghilangkan lelah.

Hasil survey terhadap 60 sekolah dasar di Kota Surakarta yang menjadi sampel penelitian mengatakan tidak terdapat satupun tempat beristirahat dalam jalur pedestrian yang ada.

\subsubsection{Petanda Jalan}

Petanda jalan merupakan bentuk peringatan terhadap kendaraan bermotor yang akan melintasi suatu kawasan yang dalam penelitian ini kawasan tersebut adalah kawasan sekitar sekolah dasar.

Hasil survey lapangan mengatakan terdapat sembilan sampel sekolah dasar atau sebesar 47,4\% pada klasifikasi sekolah favorit yang memiliki petanda jalan dan berfungsi dengan baik di sekitar sekolahnya dan sebesar 52,6\% atau 10 sekolah dasar favorit tidak memiliki petanda jalan di sekitar sekolahnya, sedangkan pada klasifikasi sekolah non favorit terdapat tujuh sekolah dasar atau sebesar $17,1 \%$ sekolah dasar non favorit yang memiliki petanda jalan dan berfungsi dengan baik di sekitar sekolahnya dan $82,9 \%$ atau 34 sekolah non favorit yang tidak memiliki petanda jalan di sekitar sekolahnya. Secara keseluruhan dari 60 sampel sekolah dasar di Kota Surakarta terdapat 16 sekolah dasar atau sebesar $26,7 \%$ sekolah dasar yang memiliki petanda jalan yang berfungsi dengan baik dan terdapat sebesar $73,3 \%$ atau 44 sekolah dasar dari total sampel yang tidak memiliki petanda jalan.

\subsection{Analisis keamanan dan kenyamanan di jalan sekitar sekolah dasar}

Sebagai salah satu pilot project kota layak anak di Indonesia, Kota Surakarta perlu memperhatikan keselamatan anak yang dalam penelitian ini dimaksudkan dengan keamanan anak menuju dan pulang dari sekolah khususnya bagi yang berjalan kaki. Lokasi sekolah dasar merupakan lokasi sekolah yang memiliki jarak ideal dalam berjalan kaki yaitu $400 \mathrm{~m}-800 \mathrm{~m}$.

Hasil survey terhadap 342 responden siswa sekolah dasar menyatakan terdapat 69 siswa atau sebesar $52,7 \%$ siswa yang berjalan kaki berasal dari klasifikasi sekolah non favorit dan 15 siswa atau sebesar $7,1 \%$ siswa yang berjalan kaki berasal dari klasifikasi sekolah favorit. Secara keseluruhan terdapat 84 siswa atau sebesar $24,6 \%$ siswa melakukan perjalanan berangkat dan 
pulang sekolah dengan berjalan kaki. Selain itu, terdapat juga 22 siswa atau sebesar $16,8 \%$ berasal dari klasifikasi sekolah non favorit dan sembilan siswa atau sebesar $4,3 \%$ berasal dari klasifikasi sekolah favorit yang hanya berjalan saat pulang sekolah saja. Secara keseluruhan terdapat 31 siswa atau sebesar $9,1 \%$ siswa yang saat berangkat sekolah diantar namun saat pulang sekolah berjalan kaki.

Dalam pengambilan kesimpulan dari responden untuk keamanan di jalan ini berdasarkan beberapa pertanyaan mengenai kejadian ataupun keadaan yang pernah dialami responden dalam melakukan perjalanan pulang dan pergi ke sekolah sehingga rasa aman maupun tidak aman bukan hanya semata-mata dari persepsi responden melainkan dari beberapa kejadian yang pernah dialami sendiri.

Dari 24 siswa sekolah favorit yang berjalan kaki baik saat pulang dan pergi ke sekolah maupun saat pulang sekolah saja terdapat 23 siswa atau sebesar $95,8 \%$ siswa yang merasa aman dan hanya satu siswa atau sebesar $4,2 \%$ yang merasa tidak aman. Sedangkan dari 91 siswa sekolah non favorit yang berjalan kaki baik saat pulang dan pergi ke sekolah maupun saat pulang sekolah saja terdapat 68 siswa atau sebesar $74,7 \%$ siswa yang merasa aman dan terdapat 23 siswa atau sebesar 25,3\% siswa yang merasa tidak aman. Secara keseluruhan, dari 115 siswa yang berjalan kaki baik saat pulang dan pergi ke sekolah maupun saat pulang sekolah saja terdapat 91 siswa atau sebesar $79,1 \%$ yang merasa aman saat berjalan kaki dan 24 siswa atau sebesar 20,9\% siswa yang merasa tidak aman saat berjalan kaki.

Selain keamanan, kenyamanan merupakan faktor yang perlu diperhatikan dalam kaitannya dengan pejalan kaki. Kondisi jalur pedestrian yang nyaman tentu akan membuat para pejalan kaki menikmati perjalanannya.

Dari 24 siswa sekolah favorit yang berjalan kaki baik saat pulang dan pergi ke sekolah maupun saat pulang sekolah saja terdapat 13 siswa atau sebesar $54,2 \%$ siswa yang merasa nyaman dan terdapat 11 siswa atau sebesar $45,8 \%$ yang merasa tidak nyaman, Sedangkan dari 91 siswa sekolah non favorit yang berjalan kaki baik saat pulang dan pergi ke sekolah maupun saat pulang sekolah saja terdapat 42 siswa atau sebesar $46,1 \%$ siswa yang merasa nyaman dan terdapat 49 siswa atau sebesar 53,9\% siswa yang merasa tidak nyaman. Secara keseluruhan, dari 115 siswa yang berjalan kaki baik saat pulang dan pergi ke sekolah maupun saat pulang sekolah saja terdapat 55 siswa atau sebesar $47,9 \%$ yang merasa nyaman saat berjalan kaki dan 60 siswa atau sebesar 52,1\% siswa yang merasa tidak nyaman saat berjalan kaki.

\subsection{Analisis deskriptif peran pelayanan} sekolah dasar dalam mendukung kota layak anak di Surakarta

Setelah melakukan tiga analisis sebelumnya, kemudian dilanjutkan analisis peran untuk mengetahui bagaimanakah peran yang dimiliki oleh sekolah dasar terhadap kota layak anak di Surakarta. Analisis peran tersebut dijabarkan sebagai berikut:

3.3.1 Peran jangkauan pelayanan sekolah dasar dalam mendukung kota layak anak

yang dimiliki sekolah favorit disebabkan oleh keinginan orang tua dalam memberikan anaknya pendidikan yang terbaik, sehingga dalam pemilihan sekolah orang tua kerap menghiraukan jarak ideal dari sekolah dasar dan biaya yang dikeluarkan demi mendapatkan pelayanan pendidikan yang diharapkan serta standar minimal untuk masuk ke sekolah favorit yang cukup tinggi. Selain hal tersebut, faktor pekerjaan orang tua yang bekerja di luar kota juga ikut mempengaruhi keputusan dalam pemilihan sekolah karena orang tua berfikiran dapat mengantarkan anaknya terlebih dahulu sebelum berangkat kerja dikarenakan perjalanan bekerja dan sekolah anak yang searah. Hal ini berdampak pada anak-anak yang berada pada jangkauan ideal dari sekolah favorit 
tetapi tidak memiliki kemampuan cukup untuk dapat lolos seleksi masuk atau anak-anak yang sudah memiliki kemampuan yang cukup namun memiliki keterbatasan dalam urusan biaya sekolah lebih memilih sekolah lain yang memiliki jarak di luar jangkauan ideal namun sesuai dengan kemampuan baik dari sisi akademis anak maupun finansial orang tua atau dalam penelitian ini disebut sebagai sekolah non favorit. Fenomena tersebut yang pada akhirnya menyebabkan beberapa dari sekolah non favorit memiliki siswa/i yang berada di luar jangkauan ideal walaupun jangkauan yang dimiliki sekolah non favorit tidak sejauh jangkauan yang dimiliki sekolah favorit. Untuk melihat perbedaan jangkauan pelayanan antara sekolah favorit dan non favorit dengan jangkauan ideal dapat melihat peta perbedaan jangkauan (Lampiran). Tentu dengan adanya fenomena tersebut tidak sesuai dengan apa yang dikatakan oleh Stein (dalam Putri, 2012) bahwa lingkungan ideal untuk fasilitas sekolah dasar yaitu minimal 400 meter dan maksimal 800 meter berjalan kaki. Sedangkan dengan jarak tempuh yang jauh membuat anak-anak menjadi tergantung kepada orang tua mereka untuk mengantar dan menjemput mereka ke sekolah (Karsten dan Vliet 2006, dalam Kingston, 2007), sehingga anak-anak menjadi kehilangan waktu mereka yang seharusnya bisa digunakan untuk bermain dan bertemu dengan temannya saat perjalanan pergi dan pulang sekolah dengan berjalan kaki.

\subsubsection{Peran kelengkapan sarana prasarana lingkungan sekolah dasar dalam mendukung kota layak anak Menurut Kingston} (2007) dalam mewujudkan kota layak anak harus memperhatikan kebetuhan anak yang dalam kaitannya dengan penelitian ini yaitu kebutuhan akan fasilitas pelayanan sekolah dasar, yaitu: adanya zona selamat sekolah, ruang dan taman bermain yang aman, tempat pembuangan sampah. Dijelaskan kembali menurut Peraturan Menteri Negara Pemberdayaan Perempuan dan Perlindungan Anak Nomor 12 Tahun 2011 tentang Indikator Kabupaten/Kota Layak anak dijelaskan bahwa dalam mewujudkan kota layak anak dalam kaitannya dengan pendidikan dapat dilihat melalui jumlah sekolah yang memiliki program dan sarana prasarana perjalanan anak ke dan dari sekolah.

Secara keseluruhan dapat disimpulkan bahwa semakin lengkapnya fasilitas pelayanan sekolah dasar yang diberikan maka semakin tinggi peran yang diberikan dalam mendukung keberhasilan kota layak anak dikarenakan lengkapnya fasilitas yang diberikan sekolah dasar berarti sekolah tersebut sudah memperhatikan kebutuhan anak yang mana hal tersebut merupakan poin penting dalam mewujudkan kota layak anak. Kondisi kelengkapan fasilitas pelayanan sekolah dasar di Kota Surakarta menjadikan aspek ini memiliki peran rendah dalam mendukung kota layak anak di Surakarta.

\subsubsection{Peran keamanan dan kenyamaan di jalan sekitar sekolah dasar dalam mendukung kota layak anak}

Pentingnya keamanan anak di jalan dijelaskan oleh Karsten dan Vliet (dalam Kingston, 2007) bahwa perlindungan terhadap anak menjadi salah satu pertimbangan dalam membangun sarana kota layak anak, seperti dibangunnya zona selamat sekolah yang berada pada permukaan jalan di depan sekolah sebagai wilayah aman bagi anak sekolah karena ketika suatu kota direncanakan untuk kepentingan mobilitas dari kendaraan bermotor dibandingkan dengan subjek pelakunya maka ada golongan yang dirugikan terutama adalah anak-anak. Mengenai keamanan tersebut juga sudah di sebutkan dalam kriteria kota layak anak yaitu anak dapat aman berjalan di jalan yang di dukung oleh 
Clarance Perry (dalam Reiner, 1968) yang mengatakan mengenai kondisi ideal lokasi sekolah dasar bahwa jaringan jalan internal harus di desain sesuai dengan skala pejalan kaki sehingga meminimalisir terjadinya kecelakaan lalu lintas.

Secara keseluruhan dapat ditarik kesimpulan bahwa semakin tinggi keamanan di jalan maka semakin tinggi peran yang diberikan dalam mendukung keberhasilan kota layak anak dikarenakan dengan tingginya keamanan di jalan membuat anak dapat bebas berekspresi dan menggunakan jalan dan trotoar sebagai taman bermain mereka, Karsten dan Vliet (dalam Kingston, 2007).

Gallion

mengatakan bahwa lingkungan sekolah dasar yang ideal merupakan integrasi dari lingkungan fisik dengan skala pejalan kaki yang memiliki fasilitas dengan jaringan jalan yang aman dan nyaman untuk di lewati. Pernyataan ini di dukung oleh Kingston (2007) bahwa kota layak anak harus memiliki lingkungan fisik yang memperhatikan kebutuhan anak yang dalam hal kenyamanan ini dapat juga dilihat melalui sistem transportasi dan manajemen lalu lintas yang ada. Ditambahkan juga oleh Patilima (2003) bahwa waktu sekolah pagi dan petang perlu dipertimbangkan karena sangat berpengaruh pada proses belajar mengajar dan kualitas siswa, karena energy yang berkurang dan suhu udara panas dapat mempengaruhi daya serap anak terhadap pelajaran. Hal ini bisa dijadikan dasar untuk menilai kenyamanan anak saat berjalan kaki karena suhu udara panas juga dapat mengurangi kenyamanan anak saat melakukan perjalanan menuju dan pulang dari sekolah.

Secara keseluruhan dapat ditarik kesimpulan bahwa semakin tinggi kenyamanan di jalan maka semakin tinggi peran yang diberikan dalam mendukung keberhasilan kota layak.

\section{KESIMPULAN}

Berdasarkan hasil analisis yang telah dilakukan dan pembahasan dengan teori yang ada, didapatkan beberapa temuan mengenai kondisi dari peran pelayanan sekolah dasar dalam mendukung kota layak anak, yaitu: kondisi jangkauan sekolah dasar di Kota Surakarta memiliki rata-rata jangkauan yang di luar jarak ideal. Kondisi dari kelengkapan sarana prasarana lingkungan sekolah dasar yang ada di Kota Surakarta memiliki rata-rata kelengkapan yang kurang lengkap. Dari keamanan dan kenyamanan di jalan, sekolah dasar di Kota Surakarta memiliki tingkat keamanan dan kenyamanan yang tinggi sehingga jika digabungkan secara keseluruhan didapatkan hasil bahwa pelayanan sekolah dasar memiliki peran dalam mendukung kota layak anak walaupun peran yang diberikan tergolong rendah karena hanya terdapat dua dari empat aspek pelayanan yang memiliki nilai tinggi.

\section{REFERENSI}

Gallion, Arthur B. 1986. The urban pattern "city planning and design". Van Nostrand Reinhold Company. USA

Kingston Beverly, etc. 2007. "Creating Child=Friendly Cities: Thes Case of Denver". University of Colorado at Denver and Health Sciences Center. USA

Patilima, Hamid. 2003. Persepsi Anak mengenai Lingkungan Kota. Jakarta

Peraturan Menteri Negara Pemberdayaan Perempuan dan Perlindungan Anak Nomor 12 Tahun 2011 Tentang Indikator Kota Layak Anak

Peraturan Menteri Negara Pemberdayaan Perempuan dan Perlindungan Anak Nomor 2 Tahun 2009 Tentang Kebijakan Kota Layak Anak

Putri, Rufia A. 2012. "Studi Kesesuaian Prinsip-Prinsip Fisik Konsep Neighbourhood Unit Dalam Penerapan Pengembangan Perumahan Formal (Studi Kasus : Perumnas Bumi Rancaekek Kencana dan Bumi Serpong Damai). Thesis 
Magister Pembangunan Wilayah dan Kota.

Institute Teknologi Bandung

Reiner, Thomas A. 1968. "The Place of The

Ideal Community in Urban Planning".

Philadelphia : University of Pennsylvia

Press

SNI 03-1733-2004 Tentang Tata Cara

Perencanaan Lingkungan Perumahan di

Perkotaan 


\section{LAMPIRAN}

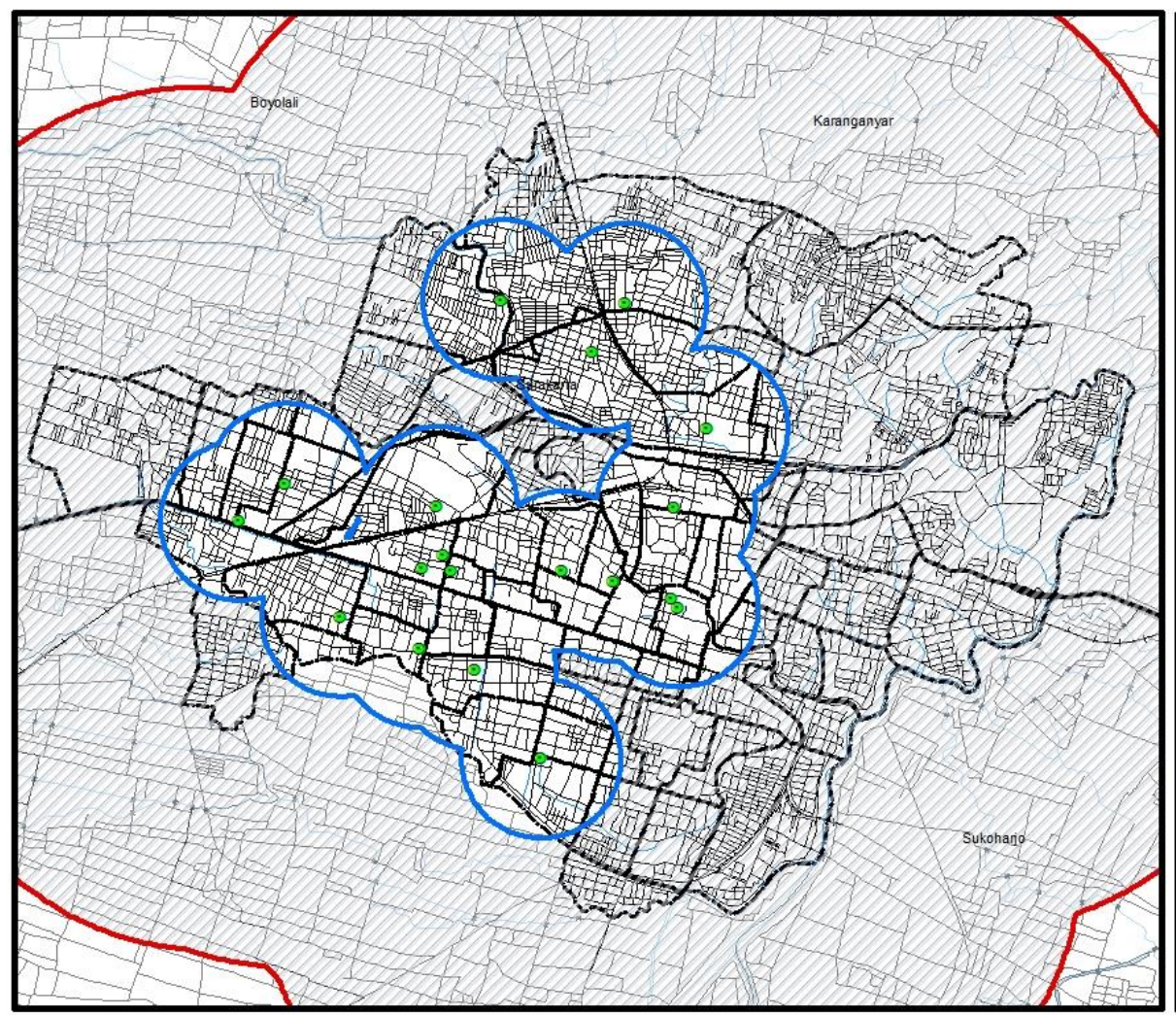

PETA PERBEDAAN

JANGKAUAN SAMPLE

SEKOLAH FAVORIT

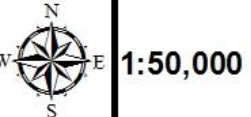

Legenda
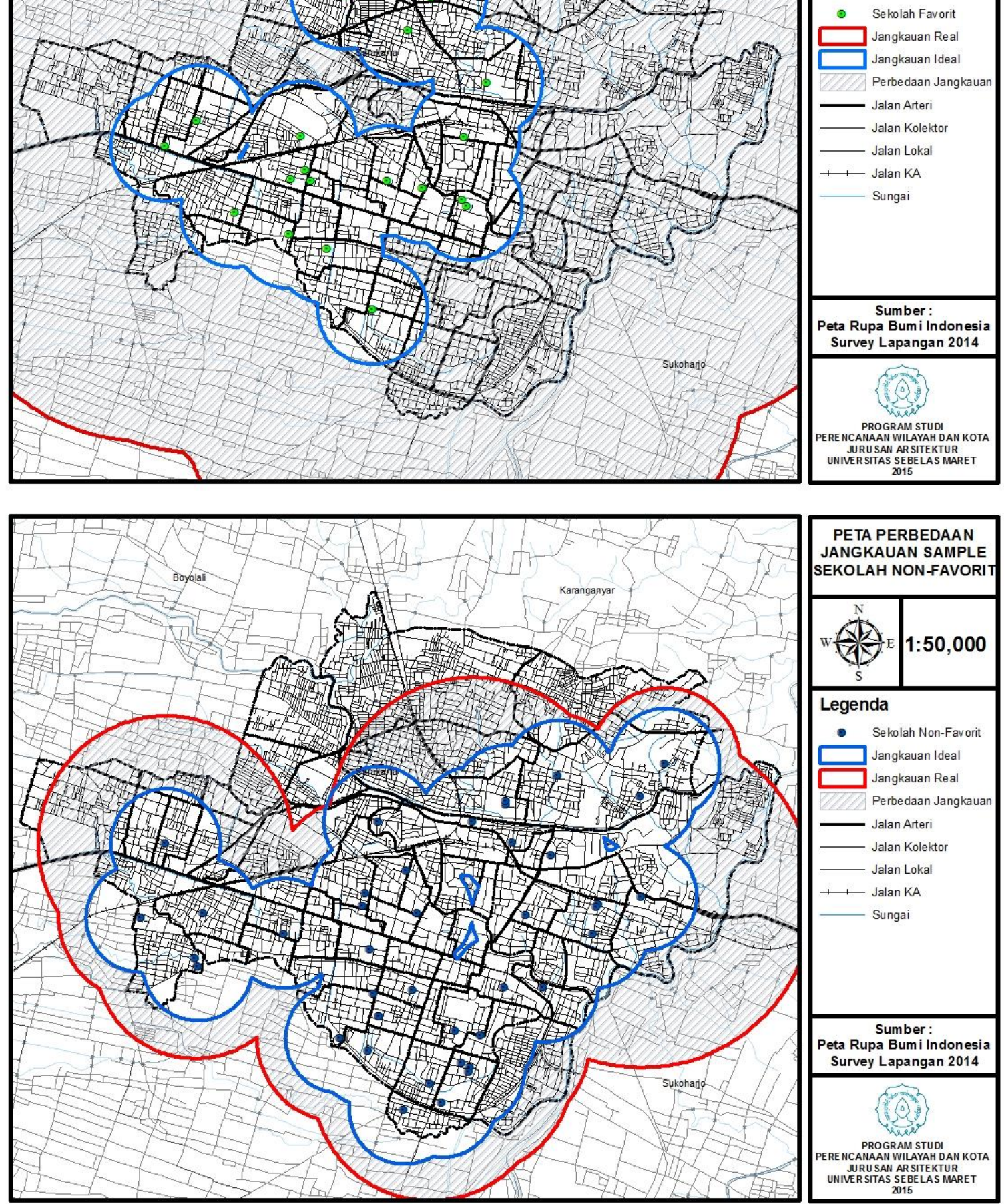